\title{
AC 2008-1069: STUDENT PERCEPTIONS OF ACADEMIC HONESTY IN AN ELECTRONIC AGE
}

\section{Carole Goodson, University of Houston}

Carole Goodson is a Professor of Technology at the University of Houston. As an active member of ASEE, she is a member of the Academy of Fellows, a past Editor of the Journal of Engineering Technology, a past Chair of PIC IV and the ERM Division, and a past Chair of the Gulf Southwest Section of ASEE.

\section{Barbara Stewart, University of Houston}

Barbara L. Stewart is Professor of Human Development and Consumer Sciences at the University of Houston where she coordinates the Consumer Science program. She earned a BA degree from Brigham Young University, a MS from Utah State University, and an EdD in Curriculum and Instruction from Brigham Young University.

\section{Susan Miertschin, University of Houston}

Susan L. Miertschin is an Associate Professor in the Information Systems Technology program at University of Houston. She is a member of the American Society of Engineering Education (ASEE), active in the Engineering Technology Division, and the Association of Computing Machinery (ACM). She is also a past Editor of the Journal of Engineering Technology.

\section{Luces Faulkenberry, University of Houston}

Luces M. Faulkenberry is an Associate Professor and Coordinator of the Electrical Power Technology program at University of Houston. He earned a B.S. degree in Physics from University of Texas at Arlington and his Ph.D. in Industrial Education from Texas A\&M University. 


\section{Student Perceptions of Academic Honesty in an Electronic Age}

Today students arrive at a university accompanied by information and communication technologies (ICT) that enable them to acquire information in support of academic endeavors from a wide array of public and private sources, including co-located and virtual peers and professionals. The ubiquitous nature of these technologies creates a tension between faculty expectations and student expectations regarding their proper, legitimate, and ethical use in an academic setting. Activities that once might have been considered "cheating" might now be considered demonstrations of the ability to collaborate, a skill highly valued in corporate America. To investigate the tension that may exist, the authors report herein a summary of background information from the literature and the results of a preliminary survey of students.

According to the Center for Academic Integrity at Duke University, "three quarters of college students confess to cheating at least once." 14 Students who participated in an exploratory survey at the University of Houston reported the following questionable behaviors involving ICT.

- "People not only use computers but cell phones, as well. Text messages are sent about answers to test items, and pictures of exams can also be sent."

- "Other students have used the internet/electronic communication to [obtain] work from [various] authors, and they do not cite these authors in their work - just changing up the words into their own; also - students submit [as their own] the work of other students from previous semesters."

While some behaviors are clearly dishonest or honest to faculty, students may have a different perception. The authors have observed that students often ask questions similar to the following.

- When is it acceptable to work together outside of class?

- Someone sent me an excel file that they turned in for this assignment last spring. Is it OK if I use it as a template for my work this fall?

- What kind of information can I use from a website and how can I use it?

- There is a lot of programming code available for free on the Internet. May I use it for this project?

\section{Review of the Literature}

Recent literature addresses numerous concerns and indicates that academic honesty continues to be an issue for faculty and students alike, and it reports on the impact of technology and existing perceptions.

Technology and Academic Honesty Academic honesty is a pervasive issue for educators such as reported by Jordan \& Elmore, ${ }^{12}$ Bikowski and Broeckelman, ${ }^{1}$ and Cordova and Thornhill. ${ }^{4}$ Indeed, Whitley ${ }^{21}$ reported on more than 100 research studies on cheating in a 30 year period. Today, increased access to ICT appears to be multiplying the opportunities and ease of access for dishonest behaviors; see Brock, ${ }^{3}$ Herkert and Cartwright, ${ }^{8}$ Higbee and Thomas, ${ }^{9}$ Holt,${ }^{10}$ and McKenzie $^{16}$. A new plagiarism, for example as described by McKenzie ${ }^{16}$ allows students to wield an "electronic shovel" in finding and saving huge chunks of information with little reading or effort. Internet-based term paper services are easily available.$^{20}$ Word processing techniques, including "copy and paste" enable students to lift, without credit, the work of others and claim it as their own. ${ }^{9}$ 
Holt ${ }^{10}$ declared, "The technology genie is out of the bottle, and there's no stuffing it back inside." He also reflected that educators are advised to weigh the ethical issues attached to Internet technologies. Academic honesty issues, while not unique to technology-based tools, are exacerbated by technology enhanced speed, access, ease of manipulation, and scope of dissemination. Holt felt that risks were magnified by the power of electronic systems. Kleiner and Lord ${ }^{14}$ similarly stated that while crib sheets and copying answers have been around for a long time, what technology has brought is an expansion of the problem with new avenues to cheat, boldness in using technology tools, and erosion of conscience.

Specific applications of technology further accelerate the rate of dishonest behavior. For example, Kennedy, et. al. reported that distance learning classes were perceived by both students and faculty as an environment where it is easier for students to cheat. ${ }^{13}$ They predicted that increases in the number of distance learning classes will lead to increases in academic dishonesty.

Student Perceptions of Academic Honesty A perception gap exists between students and faculty regarding what constitutes academic dishonesty and the severity of dishonest behavior. ${ }^{2,9}$, 19, 22 Typically, faculty view cheating more seriously than students. ${ }^{19}$ Higbee and Thomas reported that students receive mixed messages from faculty and may be accused of dishonesty when they believe they are seeking legitimate assistance. ${ }^{9}$ Indeed, a lack of clarity exists regarding the definition of cheating. 9,22

For some, what constitutes academic honesty is ambiguous. ${ }^{18}$ Quinnan suggested that formal education has not adequately provided students with crucial lessons on academic integrity. The lines between Internet research and plagiarism, collaboration and collusion, and teamwork and independent work are not clear for students. ${ }^{14}$ Jordon and Elmore reflected that many students have adopted a post-modern perspective on ethical behavior where they claim they are not cheating because they have defined for themselves what cheating is and are not violating that personal definition. ${ }^{12}$

\section{Study Procedures}

In order to obtain a clearer understanding of students' perceptions of honest and dishonest behavior, 315 students were surveyed in September 2007 at the University of Houston.

Participating students were registered in one of five classes, and most were majors in the College. However, several of the courses where surveys were administered are university core courses; thus, there was representation from a wide cross section of students. The courses varied in subject, level and delivery mode, including both on-line, hybrid, and traditional lecture. Lower division course included Poly-phase Circuits and Transformers (ELET 2301), Impact of Modern Technology on Society (TECH 1313), and Human Ecosystems \& Technological Change (HDCS 1300). Upper division courses included Computer-Based Electrical System Protection and Safety (ELET 4317), Consumer Science (HDCS 3301), Visual Merchandising (HDCS 3304), and Research Concepts in HDCS (HDCS 4300).

In order to complete the survey, students typically logged on to a WebCT class website. Completion of the survey was voluntary, and all responses were anonymous. With this system, 
responses could be downloaded into a spreadsheet by a number assigned to the student with their responses for analysis.

The instrument consisted of 12 items. Items 1 through 4 addressed four generic areas: 1) student familiarity with the institutional honesty policy, 2) student perceptions of the extent of their communication with classmates, 3) student perceptions regarding their background in the use of the web, and 4) student view of the importance of academic honesty. Item 1 simply asked students if they were familiar with the honesty policy and item 2 asked for the extent of electronic communication with classmates. Items 3 and 4 used a Likert style format; for each statement, participants responded on a five-point scale.

The second part of the survey (items 5-12) presented situations of potential academic dishonesty. A semantic differential scale was used to measure students' perception of whether the situation was academically honest or not. Students choose a value from 1 through 7, where 1 reflected a dishonest situation and 7 an honest one; on the continuum between these two extremes, respondents selected a value indicating their perception.

The third part of the survey was open-ended. Students were asked to list some ways in which they had observed other students using the Internet or other ICT in an apparent or possible violation of academic honesty policies.

The complete set of survey items is provided as an addendum.

Item responses were tabulated, and descriptive measures are used to present the results. The open ended responses are categorized by the type of technology (or other method) that was described and the use of that technology.

\section{Study Results}

The analysis was designed to consider the following issues.

- What does the data indicate regarding students' perceptions of appropriate and inappropriate uses of web sites and electronic devices in an academic context?

- What are students' perceptions regarding the conditions when it is it acceptable to work with other students?

- Based on their own observations of classmates, what do students report regarding the use of electronic communication or electronic information for their classes?

A review of the data on general background items (nos. 1 through 4) is presented in Table 1; the data revealed that $85 \%$ of the students knew about the university honesty policy and had at least skimmed it. All are familiar with internet technologies, and all concur that honesty is an important issue. The majority of participants have at least some electronic communication with class members, but a noticeable percentage does not. The authors find it surprising that $21 \%$ do not communicate electronically outside of class; note that other types of communication were not reported. 
Table 1: Student Responses to Background Items

$(\mathrm{n}=322)$

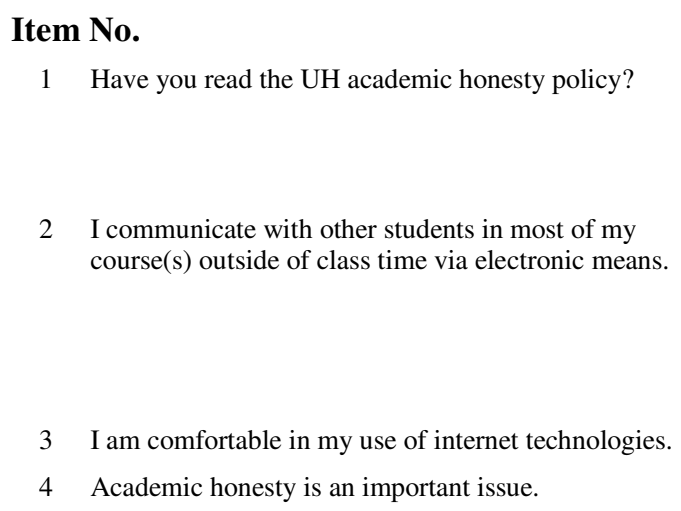

1 Have you read the UH academic honesty policy?

2 I communicate with other students in most of my course(s) outside of class time via electronic means.

3 I am comfortable in my use of internet technologies.

4 Academic honesty is an important issue.

\begin{tabular}{|c|c|c|c|c|c|}
\hline Read & Skim & No & NR & & \\
\hline $44.1 \%$ & $39.8 \%$ & $14.3 \%$ & $1.9 \%$ & & \\
\hline Often & Some & Never & NR & & \\
\hline $14.9 \%$ & $63.7 \%$ & $21.4 \%$ & $0.0 \%$ & & \\
\hline $\begin{array}{c}\text { Strly } \\
\text { Agree }\end{array}$ & & Neu. & & $\begin{array}{c}\text { Strly } \\
\text { Disgr. }\end{array}$ & NR \\
\hline $41.6 \%$ & $47.8 \%$ & $8.1 \%$ & $1.6 \%$ & $0.0 \%$ & $0.9 \%$ \\
\hline $66.5 \%$ & $28.0 \%$ & $3.7 \%$ & $0.0 \%$ & $0.3 \%$ & $1.6 \%$ \\
\hline
\end{tabular}

Items 5 through 12 measured perceptions in specific situations. Descriptive methods were used to analyze this information. In order to determine those situations that were perceived as clearly honest or dishonest and those situations that were perceived as presenting some ambiguity, responses were collapsed and categorized into one of three areas: Honest, Neutral, or Dishonest. The summarized data are shown in Table 2 with the item concepts severely abbreviated. Refer to the addendum for the complete statement of the item.

The data indicated that communicating outside of class and using properly cited web resources are clearly viewed as honest behavior. (It is surprising that $5 \%$ think this is dishonest, which may represent an error in the item design.) Purchasing a paper and/or using a free paper from the web, without citation, are clearly perceived as dishonest behaviors.

There are several items that support the concept that students do not know or are unclear about what is dishonest with respect to using ICT to support class activities. This result matches findings from the literature. Areas that seem to present conflicting views include the following. The electronic review of classmates' work to clarify class issues was viewed as dishonest behavior by $40 \%$ of the participants. Forty-five percent of the participants are at least neutral about the practice of resubmitting work done for one class to meet the requirements of another class. (Perhaps there is ambiguity in the interpretation of this item because a response may depend on the student's understanding of the instructor's directions.) Likewise, $45 \%$ of students are at least neutral about the practice of doing electronic team work with no credit to team members. Almost one-forth of the students viewed the practice of using modified web text with no citation as honest behavior. 
Table 2: Student Perceptions to Honesty Items

$(\mathrm{n}=322)$

\section{Item No.}

5 Web text with citation

8 Electronic communication to clarify

11 Electronic review of others' work to clarify

12 Resubmit work

7 Electronic team work with no credit to members

6 Modified web text with no citation

9 Use web site free paper with no citation

10 Purchased paper with no citation

\begin{tabular}{crrr}
\hline H & N & D & NR \\
7_6_5 & \multicolumn{4}{c}{ 4 } & 3_2_1 & \\
\hline \hline $88 \%$ & $2 \%$ & $7 \%$ & $4 \%$ \\
$82 \%$ & $7 \%$ & $5 \%$ & $5 \%$ \\
$37 \%$ & $16 \%$ & $41 \%$ & $6 \%$ \\
$33 \%$ & $12 \%$ & $51 \%$ & $5 \%$ \\
$25 \%$ & $17 \%$ & $53 \%$ & $5 \%$ \\
$24 \%$ & $12 \%$ & $59 \%$ & $5 \%$ \\
$8 \%$ & $1 \%$ & $85 \%$ & $6 \%$ \\
$7 \%$ & $1 \%$ & $87 \%$ & $5 \%$
\end{tabular}

\section{Figure 1: Student Perceptions to Honesty Items}

$(\mathrm{n}=322)$

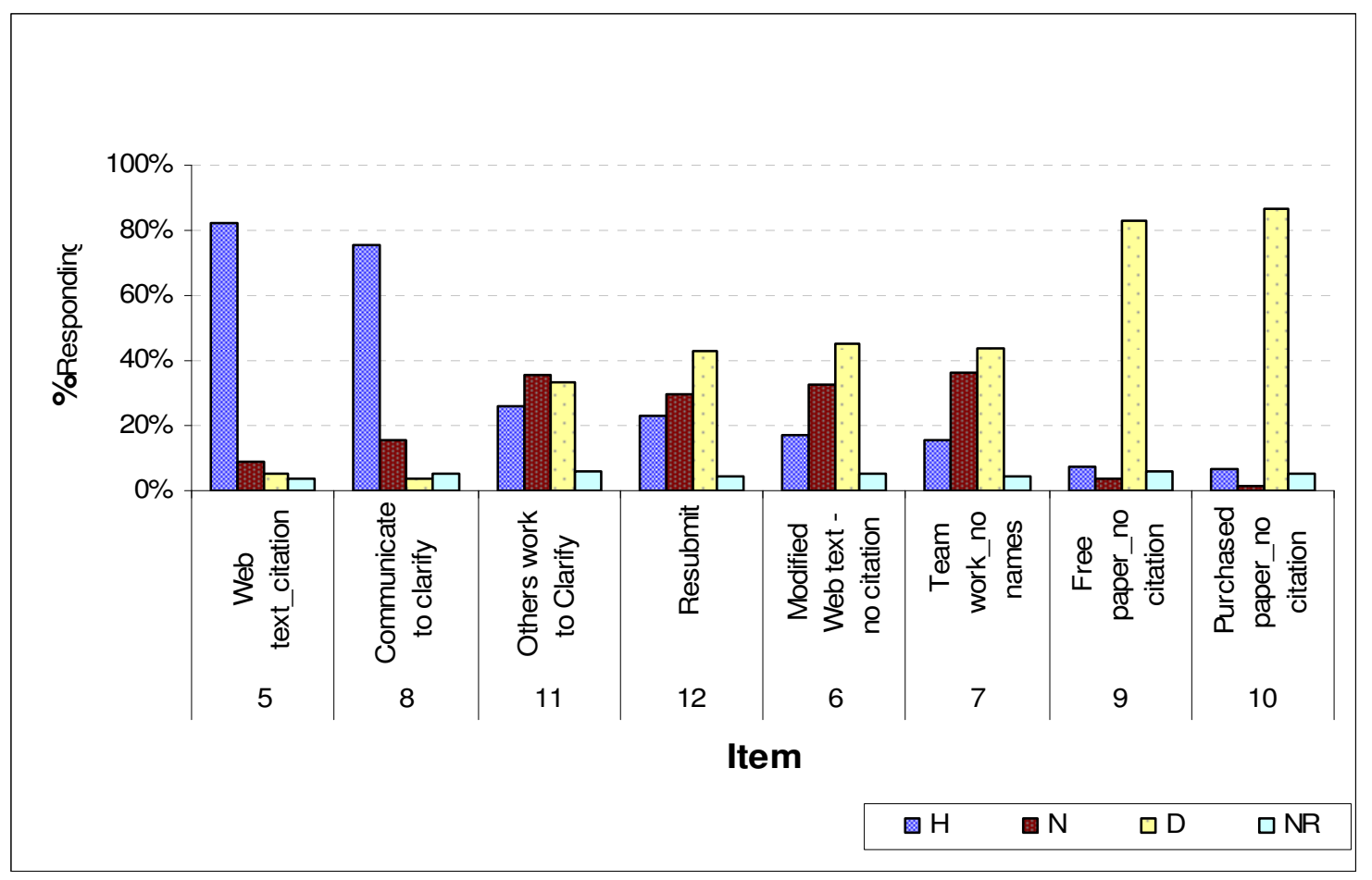


Student comments revealed some interesting perceptions. Review of the categorized comments showed that $25 \%$ of the issues were concerned with the proper citation of electronic information. The most common type of response related to this category read, "The most obvious way would be straight 'copy and paste' directly from website to paper without any citation." Related types of reported incidents included:

- "[another way is] the altering of a copied and pasted section of text to switching words around and changing it [the words] to disguise the violation. "

- "using fake web sites,"

- "use of a few key words without citation - I have seen students who really didn't know if this is plagiarism,"

- "linking several papers to make a paper seem as though they created it."

Approximately $15 \%$ of the reports addressed the use of technology (such as cell phone to text message and e-mail) for assistance on exams and other assignments including the following.

- "Emailing code to be copy/pasted in program"

- "I saw a girl taking a test on-line and she e-mailed her own notes to herself. So she used that when taking the test."

- "Sending messages via text message on a phone"

Students also reported on working with others to complete an exam such as demonstrated in the following comment, "several students [were] working on one online test to find all the answers and using those answer to get perfect answers on their test."

Five percent of the responses concerned buying papers from an internet source, and only a few responses alluded to the use of free papers in totality.

\section{Methods to Encourage and Enforce Academically Honest Behavior}

The literature presents ideas for encouraging and enforcing academically honest behavior. Bikowski and Broeckelman recommended an educational framework for nurturing a culture that values academic honesty. ${ }^{1}$ The framework they described involved both students and faculty. Student efforts included a required writing course for new graduate students and the creation of a student academic honor council to lead efforts to develop a college honor code. Faculty efforts included workshops and a faculty academic honor council to promote teaching practices to reduce dishonesty.

Communication, in many forms was seen as part of the solution. Braun, Stallworth, \& Cram viewed communication as necessary to bridge the expectation gap between students and faculty. ${ }^{2}$ Clear written policies were suggested by Denison Writing Center ${ }^{5}$ and by Hricko; ${ }^{11}$ instructing students on what constitutes academic dishonesty were cited by Hricko, ${ }^{11}$ Quinnan, ${ }^{18}$ and others. An ethics seminar was one idea for creating a culture of honesty. ${ }^{14}$ Another idea was for faculty to model honest behaviors. ${ }^{5}$

More specifically, alterations to assignments and testing practices were suggested to foster academic honesty. Changing assignments required faculty being aware of what is available to 
students on the Internet. ${ }^{5,17}$ Other suggestions included creating assignments with goals, instructions, and audiences specific to an individual course, ${ }^{6}$ requiring oral presentations, ${ }^{17}$ and requiring electronic submissions to enable the use of plagiarism surveillance software. ${ }^{15,17}$

Recommended changes to testing practices included increased training for proctors, ${ }^{14}$ altering exams so that there are multiple versions or versions electronically customized for each student based on answers to each item, ${ }^{4,14}$ creating restricted environments for online exams, ${ }^{14}$ banning all electronic equipment during exams and disabling wireless in classrooms, ${ }^{3}$ and using technology such as digital cameras for surveillance or biometric scans to verify the identity of the test taker. ${ }^{14}$

The authors' experience leads to the following additional suggestions for supporting a culture of academic honesty.

- Include written or verbal discussion of why academic honesty is important to the faculty member, the institution, and every student. Set the tone.

- Have the students sign and submit a promise that they will behave honestly and ethically. Some will take this seriously and some will not, but it will help set the tone.

- Define both honest and dishonest behaviors with respect to individual assignments, group assignments and exams. Explicitly state consequences for dishonest behaviors. This may have to be done on an assignment-by-assignment basis.

- Vary exams every semester. It is a lot of work, but evaluation and assessment of learning is part of the job of a faculty member. Faculty members must take this aspect of the job seriously and perform it well.

- Online exams must be created from a large text bank of items. Assuming this use of technology is in place, do not give online exams to all students in one specific one or two hour time window. If you do, then the students know they are all online at the same time and available via instant messaging (many course management systems have instant messaging built in) or cell phone.

- In addition to exams, seek alternative ways to assess student achievement. Concept mapping is an activity that can reveal much about what a student understands and copying is readily identifiable if the class size below 40 .

\section{Future Directions}

This exploration into issues related to academic honesty and ICT reveals a broad field for further research. Appropriate application of ICT to prevent academic dishonesty is a technical research area with potential. Digital signatures and encryption are technologies being developed and deployed in answer to privacy and security issues; perhaps these have application here as well. Why students cheat is an opportunity area for sociological/psychological research. Further in this realm might be investigating the question of whether ICT and globalization is changing the definition of honest behavior in general. After all, there is a community of people, for example, who believe that text, music, and multimedia should be freely distributed over the Internet, and that if this is allowed/encouraged, the free market will determine how profit will be passed on to the creators. Also, in professional practice, such as medicine, it is openly acknowledged that there is more factual knowledge available than can be cognitively processed by most humans. Thus, for a professional to be effective, he/she must be able to access quality information in a timely way and reprocess it to solve problems. What is of most value to the economic enterprise 
is not factual knowledge stored in the worker's brain, but the ability of the worker to share and apply this expertise to solve a problem. Perhaps we, as educators, need to refocus on this aspect of cognition in redesigning evaluation/assessment systems that reflect students' abilities to share, apply, and problem solve using their factual knowledge.

\section{References}

1. Bikowski, D., \& Broeckelman, M. (2007). An educational framework for nurturing a culture of academic honesty. ASEE Conference Proceedings 2007, retrieved November 30, 2007 from http://www.asee.org/acPapers/AC\%202007Full2114.pdf.

2. Braun, R. L., Stallworth, H. L., \& Cram, D. P. (2005, January 17). The academic honesty expectations gap: An analysis of student and faculty perspectives. Retrieved September 6, 2007 from SSRN database: http://ssrn.com/id649765.pdf.

3. Brock, R. (2004, July 16). Wired for cheating. Chronicle of higher Education, 50(45), A27-A28. Retrieved September 12, 2007 from EBSCOHost database.

4. Cordova, J. L., \& Thornhill, P. (2007, May). Academic honesty and electronic assessment: Tools to prevent students from cheating online. JSCS, 5, 52-54. Retrieved September 6, 2007 from http://www:ccsc-ms.org/Journal/MS8.pdf

5. Denison Writing Center. (2007). About academic honesty. Retrieved September 6, 2007 from http://www.denison.edu/academics/writingcenter/academic_honesty.html.

6. EKU TLC Teaching Tips. College Integrity. (2007). Retrieved September 6, 2007 from http://www.tlc.eku.edu/tips/college_integrity/.

7. Faculty perception on student academic honesty. (2003, spring). College Student Journal, 37 (3), 327-33. Retrieved September 10, 2007 from WilsonWeb database.

8. Herkert, J. R. \& Cartwright, G. P. (1998, January/February). The conscience of computer science: Organizations that target the ethical \& social implications of information technology. Change, 30, 61-63. Retrieved September 10, 2007 from WelsonWeb database.

9. Higbee, J. L., \& Thomas, P. V. (2002, Fall). Student and faculty perceptions of behaviors that constitute cheating. NASPA Journal, 40(1), 39-52. Retrieved September 10, 2007 from WilsonWeb database.

10. Holt, M. E. (1998, Summer). Ethical considerations in Internet-based adult education. New Directions for Adult and Continuing Education, (78), 63-9. Retrieved September 10, 2007 from WilsonWeb database. 
11. Hricko, M. (1998). Internet plagiarism: Strategies to deter academic misconduct. Retrieved September 6, 2007 from http://www.mtsu.edu/ itconf/proceed98/mhricko.htm.

12. Jordan, W., \& Elmore, B. (2006). Engineering ethics and moral theories: A student perspective. ASEE Conference Proceedings 2007. Retrieved November 30, 2007 from http://www.asee.org/acPapers/code/getPaper.cfm?paperID=11233\&pdf=2006Full1015.pdf

13. Kennedy, K. Nowak, S., Raghuraman, R., Thomas, J., \& Davis S. F. (2000). Academic dishonesty and distance learning: Student and faculty views. College Student Journal, 34(2), 309-314. (17)

14. Kleiner, C. \& Lord, M. (1999, November 22). The cheating game. U.S. News \& World Report, 127(20), 54, 9p, 6c.

15. Losh, E. (2007). Honor coding: Academic dishonesty and the rhetoric of plagiarismdetection software (or how I learned to stop worrying and love Turnitin.com). Retrieved September 5, 2007 from http://www.digitalrhetoric.org/honorcoding.pdf.

16. McKenzie, J. (1998, May). The new plagiarism. The Educational Technology Journal, 7(8). Retrieved September 6, 2007 from http://fno.org/may98/cov98may.html.

17. McMurty, K. (2001, November). E-cheating: Combating a $21^{\text {st }}$ challenge. THE Journal, 29(4) p. 36-40. Retrieved September 12, 2007 from EBSCOHost database.

18. Quinnan, T. (2007, February 13). Academic honesty and the "Millenials". Academic Leadership Live: The Online Journal, 2(1). Retrieved September 6, 2007 from http:www.academicleadership.org/leader_action_tips/Academic_Honesty_and_the_Mille nials.Shtml.

19. Smith, J. N., Nolan, R. F., \& Dai, Y. (1998, June). Faculty perception of student academic honesty. College Student Journal, 32(2), 305-310. Retrieved September 10, 2007 from WilsonWeb database.

20. Tommaney, S. (2001, January 18). Information vital to prevent electronic cheating. University of Houston Campus News. Retrieved September 6, 2007 from http://www.uh.edu/uhcnonline/2001/01jan/electronic.htm.

21. Whitley, B. E. (2001). Gender difference in affective responses to having cheated: The mediating role of attitudes. Ethics \& Behavior, 11(3), 249-259, Retrieved September 12, 2007 from EPNET database

22. Yeo, S. (2007, June). First-year university science and engineering students' understanding of plagiarism. Higher Education Research and Development, 26(2), 199216. Retrieved September 11 from EBSCOHost database. 


\section{Survey}

Respond to each item to indicate your opinion or knowledge about issues of academic honesty. Note that Web CT survey submissions are anonymous when results are viewed by the instructor. The instructor is informed of which students completed the survey, but not how each individual answered each item.

1 Have you read the UH academic honesty policy?

2 I communicate with other students in most of my course(s) outside of class time via electronic means.

3 I am comfortable in my use of internet technologies.

4 Academic honesty is an important issue.

$\begin{array}{llll}\begin{array}{l}\text { Yes, I have } \\ \text { read it }\end{array} & \begin{array}{l}\text { I skimmed it, } \\ \text { quickly }\end{array} & \begin{array}{l}\text { No, I have not read } \\ \text { it }\end{array} \\ \text { often } & \text { sometimes } & \text { never } & \\ & & & \\ \begin{array}{l}\text { Strongly } \\ \text { Agree }\end{array} & \text { Agree } \quad \text { Neutral } & \text { Disagree } & \begin{array}{l}\text { Strongly } \\ \text { Disagree }\end{array} \\ \begin{array}{l}\text { Strongly } \\ \text { Agree }\end{array} & \text { Agree N Neutral } & \text { Disagree } & \begin{array}{l}\text { Strongly } \\ \text { Disagree }\end{array}\end{array}$

For each of the following, evaluate each item as a number 7 through 1, where you view 7 is the most academically honest behavior and 1 is the least academically honest behavior.

5 Including word-for-word text from a web site within quotation marks and citing the original author when submitting an assignment.

6 Using a fact or idea from a web site and presenting it without citation in an assignment, as long as it is presented in my own words

7 Working in teams and then each person presents work independently, without naming team members

8 Communicating with other students in the same course(s) outside of class time via electronic means in order to find out the url (web location) of the next reading assignment

9 Using a free paper available on the Internet (without citation) as all or part of a course assignment

10 Purchasing a paper available on the Internet (without citation) as all or part of a course assignment

11 Obtaining in electronic form the work of another student previously enrolled in the course in order to understand a concept

12 Resubmitting your own work from course A to meet the requirements of a different course $B$.

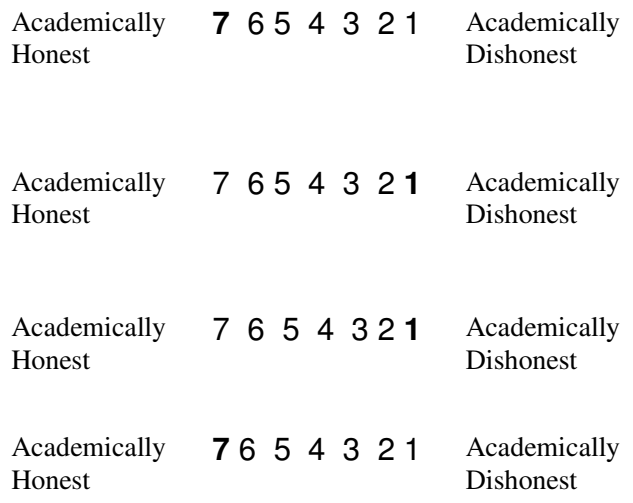

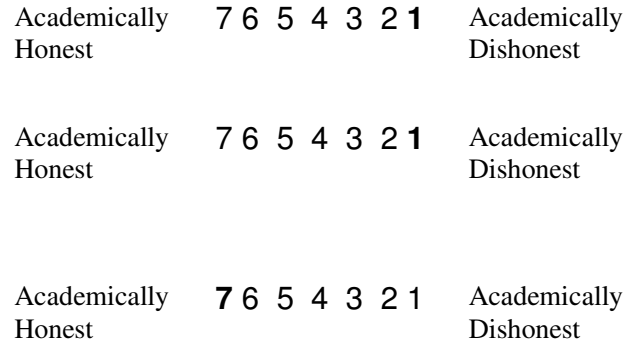

Academically Honest

List some ways in which you have observed other students using internet or other electronic communication in violation of academic honesty policies? 